\title{
イギリスにおける農業人材育成の現状と展望
}

一農業教育機関の役割に着目して一

\author{
内山 智裕 (三重大学) \\ Alan Mcgeorge \\ Ian Whitehead (Plymouth University)
}

\section{The Current and Possibly Future State of Human Resource Development in England's Farming Industry: The Role of Agricultural Education Institutions}

\author{
Tomohiro Uchiyama (Mie University) \\ Alan Mcgeorge \\ Ian Whitehead (Plymouth University)
}

\begin{abstract}
The study focuses on agricultural colleges and universities in England, which are responsible for delivering the formal education to individuals for the farming industry; it reveals the current state and future prospects of those institutions, based on a number of case studies. In England, enrollment in agricultural courses in such institutions has increased since the 2000s. According to a series of interviews with five key cases, the majority of applicants are from farming families. Although a large proportion of alumni with farming backgrounds
\end{abstract}

\section{1.はじめに}

担い手の減少・高齢化が進む我が国農業にとって, 次世代の人材育成は喫緊の課題である。良質の若い 担い手を量的に育成していかなければならない一 方, 従来の家族経営内の親子間継承のみにそれを委 ねるには限界がある, といら背景に鑑み, 人材の供 給源を農業後継者以外にも広げ，その育成を教育制 度などに託し，就農に向けた障害を各種政策支援で 軽減することにより，良質な担い手の育成を図るこ とが求められている.

このような人材育成の問題は，我が国に限ったも のではなく，先進国農業に共通して見られる。本論 では英国を事例に，特に農業教育機関の人材育成機 能の現状と展望について分析を行う。英国では, Policy Commission on the Future of Farming and Food ４］が，「人々が農業といら産業を去るとき，そ饥を 補充しょうとする人々の存在が望まれ」,「近い将来, go into farming, it is difficult for those with no farming background to engage in farming, mainly on account of lack of capital. In England, agricultural colleges and universities are required to provide the farming industry with a sound supply of human resources from a variety of backgrounds; it is also imperative, however, for such institutions to provide people who lack a farming background with opportunities to enter into farming, in addition to education opportunities.

トレーニングを十分に受けた若い農業者が大量に必 要になる」と問題提起していること, 労働力人口に 占める農業者の割合が先進諸国の中でも最低水準に あること，近年に高等教育改革と農学系学部の再編 が行われたことなどがその理由である.

な抒，英国はイングランド・ウェールズ・スコッ トランド怙よび北アイルランドから成る連合王国た が，本論では主にイングランドについて取り上げる. ただし，統計データの制約上，全国（UK）を取り上 げる箇所もある．英国では 1999 年までに各地域への 権限移譲が行われ，それ皆れが独自の教育システム を導入できるようになった。したがって，イングラ ンドに打ける教育制度が連合王国内の他地域には必 ずしも適用されないことには留意が必要である.

\section{2. 英国農業の人材の賦存状況と教育制度}

英国農業では，歴史的に農業労働者や雇われマネ 
ジャーが比較的分厚く存在したことが知られている. 例觉ば，農業労働者には農業賃金指令 (Agricultural Wage Order）により職位に応じた賃金水準が保障さ れているし (内山 [5]), 今日でも雇わ秃マネジャ一 が一定数存在している (内山 [6])。ただし，フル タイムの雇用労働力は減少を続けるなど, 農業キャ リアの確立や農業階梯の実現は今日では容易ではな い（内山 [7])。表 1 は英国（UK）に抢汀農業従 事者の推移を示したものだが，経営者，雇われマネ ジャ一，労働者など全ての層において減少を続けて いることがわかる. 特に, 若者の就農が減少し, 従 事者の高齢化進展が問題視されてきた．この点は我 が国と程度の違いはあるものの, 問題意識を共有す るといえる。

イングランドに打ける教育制度を概観すれば1), 5 歳〜 16 歳までが義務教育期間であり（ただし， 2015 年までに 17 歳まで引き上げられる予定), 11 歳までが小学校 (elementary school), 16 歳までが 中学校 (secondary school) となっている. 中学校は 前半部（11 14 歳） と後半部（14～16 歳）に分 けられ, 後半部は職業訓練コース $(14 \sim 16$ 歳), 義 務教育後の 18 歳まで継続する GCSE A レベル (General Certificate of Secondary Education）向けのコースな どがある. 16 歳以降は高等教育 (Higher Education) 向けと職業訓練向けの学校に分か水，18歳からは 大学などの高等教育もしくは 16 歳以降から引き続

\section{表 1. 英国（UK）における農業従事者の推移（単位:} 千人)

\begin{tabular}{|c|c|c|c|c|c|c|}
\hline & 1985 & 1990 & 1995 & 2000 & 2005 & 2010 \\
\hline 常勤フルタイム & 157 & 125 & 103 & 83 & 66 & 64 \\
\hline 常勤パートタイム & 59 & 58 & 54 & 42 & 39 & 39 \\
\hline 季節・臨時雇用 & 97 & 91 & 84 & 63 & 64 & 56 \\
\hline 労働者計 & 313 & 274 & 241 & 188 & 169 & 159 \\
\hline 雇われマネジャー & 8 & 8 & 8 & 11 & 15 & 11 \\
\hline フルタイム経営者 & 204 & 188 & 174 & 165 & 149 & 134 \\
\hline パートタイム経営者 & 95 & 107 & 119 & 153 & 162 & 161 \\
\hline 農業従事配禺者 & 78 & 79 & 78 & - & - & 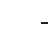 \\
\hline 経営者計 & 376 & 374 & 371 & 318 & 311 & 295 \\
\hline うち35歳术両 つ嗐哈(\%) & - & 7 & 6 & 5 & 3 & 3 \\
\hline 䏦65歳以上の割哈 & - & 23 & 23 & 25 & 31 & 32 \\
\hline 農業従事者計 & 697 & 656 & 620 & 516 & 494 & 466 \\
\hline
\end{tabular}

注 : 1995 年と 2000 年のデータには連続性がない.

資料：Defra, Agriculture in the United Kingdom 各年度版
いての継続教育（Further Education）に分かれる. 2001 年に継続教育と高等教育の橋渡しの制度と して創設されたのが基礎学位（Foundation Degree） である. 基礎学位は, 18 歳以降を対象に 2 年間（フ ルタイム換算）で特定の分野に打情基礎的な学習 を行らものである．修了者は学士コースへの編入資 格を得られ， 1 年間の追加学習で学士取得が可能と なっている，学士教育を行ら大学が基礎学位のコー スを併設している場合も多い。

\section{3. 農業分野をめぐる継続・高等教育の現況 （1）農業大学の状況}

英国では，1947 年に全ての州（county）で農業 教育機関の設立が要請されたことが戦後の農業教育 の礎となっている，当時の農業教育は高等教育では なく，継続教育や職業訓練が想定されていた。その 後, 継続教育を行ら農業教育機関は徐々に整理・統 合されてきた。これらとは別に，以前からの高等教 育機関が農業コースを設置・整備してきた。今日， 英国（UK）で農業関連の継続教育・高等教育機関 の連合組織 LANDEX（Land Based Colleges Aspiring To Excellence）に加盟している正会員組織は $36 て ゙$ ある（複数のキャンパスをもつ同一の大学がキャン パス毎に会員登録しているケースを含む).

英国に扣いても，農業従事者の減少に並行し，大 学等の農業コース在籍者は減少しているとされてき た。図 1 は，1996～2010年度の英国（UK）の大 学に打忷る農業系コースの在籍学生数の推移を及た ものだが， 2003 年までは 15,000 人前後で横ばい。 微減の傾向が続いていたことがわかる. 英国の大学 全体の在籍者数が増加していたため（1996/97 年度 から 2003/04 年度にかけて 25.3\%増)，農業系在籍 者の全体に占める割合は同期間に $0.87 \%$ から $0.67 \%$ に減少していた ${ }^{2}$ ．ところが，それ以降は増加傾向 が顕著になって挆り，2010 年度には農業系在籍者 数が 20,000 人を突破し，全体に占める割合も $0.83 \%$ まで回復してきていることも同図は示している.

また，農業系コースをさらに細かくみると，2003 年度以降に全体が増加に転じたとはいえ，狭義の農 業コースの在籍者数は伸び悩んで打り，全体の増加 は food science や animal science が支える構造であっ た，実際，英国の農業系大学・学部においても，我 が国と同様，「農業」だけでなく，「土地由来（land- 
based）」「環境」などをキーワードにした名称をコー スに付しているヶースが多い。ただし，これも 2009 年以降は狭義の農業コースも在籍者が急増し ていることがわかる ${ }^{3)}$.

\section{（2）既存農業者の教育水準}

一方, 現在の農業者が受けてきた教育水準に関す るデータは限られている.

Gasson［3］は，1990 年代中盤までの各種の調査研 究をレビューし, 農業者の教育水準が農業者の行動 に大きな影響を与えると考兄られるが, 統一的な統 計が存在しないことを指摘している. また, 教育水 準は農業経営の規模や立地・農業経営者の年齢など にも影響を受けるが, 英国の労働力調査（Labour

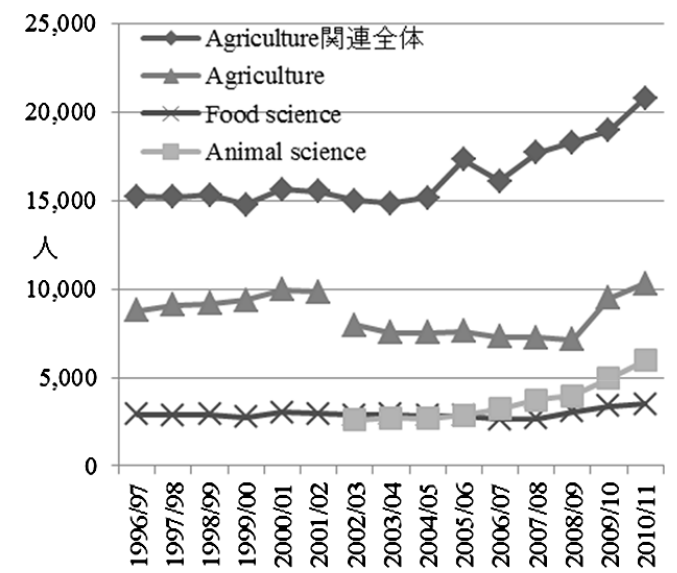

図 1. 英国の大学（UK）における農業系コース在 籍者の推移

(資料：HESA Student Record 各年度版)
Force Survey）の結果を引用し，学士以上の学位を有 する農業者の割合は，他産業のスモールビジネス経 営者のそれと比べ低位にとどまっていること（その 他産業 $16.4 \%$ に対し農業者 $4.1 \%$ ), 今後も教育の効果 を注視する必要があることなどを明らかにしている.

このように，英国に打ける農業教育機関は，在籍 者が近年増加するなぞ，農業の人材育成に一定の役 割を果たしていると考えられるが，その実態につい ては明らかでない部分が大きい。

\section{4. 事例分析}

\section{（1）対象事例の概況}

本論では, 上記の動向に鑑み, 継続教育・高等教 育を実施している農業大学に和ける入学者・卒業生 の動向，教育カリキュラムの内容などについて聞き 取り調査を 2012 年 3 月拈よび 9 月に実施した。調査 対象としたのは表 2 に挙げた 5 大学である. 以降の 記述は主に各大学に扔ける聞き取り調查に基づく.

\section{表 2. 調查対象大学の概況}

\begin{tabular}{c|c|c|c}
\hline 大学名 & 所在州 & 設立年 & 提供コース \\
\hline HarperAdams & Shropshire & 1901 & FD $\sim \mathrm{Ph} . D$. \\
\hline RAC & Gloucestershire & 1845 & FD $P$ Ph.D. \\
\hline Bicton & Devon & 1947 & FD \\
\hline Nottingham & Nottinghamshire & 1948 & FD $\sim \mathrm{Ph} . D$. \\
\hline Duchy & Cornwall & 1986 & FD MSc \\
\hline
\end{tabular}

注: RAC は Royal Agricultural College, FD は Foundation Degree を表す

資料 : 各大学資料より筆者作成

表 3. 対象事例における農業コース入学者の動向

\begin{tabular}{|c|c|c|c|c|}
\hline & 志願数 & 農場出身の有無 & 国籍 & 性別 \\
\hline $\begin{array}{l}\text { Harper } \\
\text { Adams }\end{array}$ & $\begin{array}{l}\text { 授業料高騰を前に一 } \\
\text { 時的に增えたが, 安定 } \\
\text { 的に推移。 }\end{array}$ & $80 \sim 85 \%$ が農場出身。 & $\begin{array}{l}\text { ほとんど英国。国外 } \\
\text { は1\%くらい。 }\end{array}$ & $\begin{array}{l}\text { FD80〜90\%男性。 } \\
\text { BScでは75〜80\% } \\
\text { 男性。 }\end{array}$ \\
\hline RAC & $\begin{array}{l}\text { 増加。求人が多いこと } \\
\text { が要因。 }\end{array}$ & $\begin{array}{l}\text { 7割は農場出身。昔はほぼ全 } \\
\text { 員。3代続けての入学者も。 }\end{array}$ & $\begin{array}{l}\text { 一部のコースを除き, } \\
\text { 英国人が多い。 }\end{array}$ & $\begin{array}{l}\text { 馬術コースを除き, } \\
\text { 男性が多い。 }\end{array}$ \\
\hline Bicton & $\begin{array}{l}\text { 減少。農業の勉強が } \\
\text { 学生の選択肢に入ら } \\
\text { ず。 }\end{array}$ & 農場出身者は約 $50 \%$ 。 & 州内がほとんど。 & 男子が多い。 \\
\hline Nottingham & 増加傾向 & \begin{tabular}{|l|} 
入学者の7割は農場出身者だ \\
が、それ以外も增加。生物学や \\
世界の食料問題に興味を持つ非 \\
農家の学生。
\end{tabular} & $\begin{array}{l}\text { ほとんんどがイングラン } \\
\text { ド出身 }\end{array}$ & $\begin{array}{l}\text { 10年前は85\%が男 } \\
\text { 性 } \\
\text { 昨年・今年は } 50: 50\end{array}$ \\
\hline Duchy & 増加傾向 & 約7割は農場出身 & 英国内中心 & $\begin{array}{l}\text { 農業コースは男性 } \\
\text { 中心 }\end{array}$ \\
\hline
\end{tabular}

資料：聞き取り調査による 


\section{（2）対象事例における入学・卒業の動向}

対象事例に打怕農業コ一ス入学者の動向をまと めたのが表 3 である．大学毎に固有の事情があるも のの, 図 1 でも確認したように，全体として志願者 数が増加傾向にあること, ただし入学者の多くは農 場出身であり，農業を志寸場合，卒業後に自家農場 に戻る場合が多いこと, 国籍は英国（イングランド） が活とんぞであり，性別も男性が多いことがわかる.

一方, 全ての大学に打いて志願者が増えているわ けではないことも確認できた。例えば，Bictonでは 農業コースの志願者は減少している，その原因とし て, 同大学の担当者は, 農業そのものが魅力的でな いことを構造的要因として挙げるとともに, 固有の 事情として, 予算のひっ迫によるコースの運営難や, 近隣の農業大学との学生獲得競争を指摘している.

卒業生の進路抢よび問題点については, 表 4 亿示 した．卒業生の少なくない割合が就農しているが， その多くは自家農場への就農である. 就農への最大 の障壁は，地価の上昇捺よび経営基盤確立に必要と なる農場面積の拡大に伴ら資本不足であり，自家農 場に戻らない形での就農は難しいこと, 大規模経営 などへの就職は 1 つの方策であるが, 採用の絶対数 が少ないことが各大学担当者の指摘する共通事項で ある. 大学によっては, 農業コンサルタントや関係
機関への就職が多いところもある.いずれにしても， 農場出身者でない場合は，就農を卒業後の直接的な キャリアとして想定するのは難しい，そして，各大 学の担当者の問題意識は, 近年の志願者数の増加に 安心することなく，農業従事者数の長期的な減少の 下で，国外の学生，非農家の学生なぞをいかに引き 付けるかといら点にあることがわかる.

な抒, 農業コース卒業後の学生の就農動向を調査 したものとして, ADAS [1] が 2003 年時点での農 業大学卒業生に対して行った調査結果がある。その 結果によれば，卒業生の 65\%は卒業時に農業をする 意思があったが，らち実際に就農に至ったのは $42 \%$ （全体の 27\%）にすぎない，ここで卒業時の就農意 思について農場出身者・非農場出身者別にみると, それぞれ 80\%，36\%であった。非農場出身者の就農 意思は農場出身者に比べ低いが，それでも 3 割超が 就農意思を持っていることが確認できる。また，卒 業時に就農意思があり実際に就農した者は，農場出 身者で全体の 38\%であったのに対し，非農場出身者 では同 $6 \%$ といら結果となっている，さらに，卒業 時に就農意思があったにも関わらず就農に至らな かった者に対して, 就農の障壁となった事項を $3 つ$ まで挙げてもらったところ，1位が農業の収益性の 低さ $(60 \%) ， 2$ 位が資本不足 $(51 \%) ， 3$ 位が家族

表 4. 対象事例における進路の動向および問題点

\begin{tabular}{|c|c|c|c|}
\hline & 卒業率 & 進路 & 問題 \\
\hline $\begin{array}{l}\text { Harper } \\
\text { Adams }\end{array}$ & $\begin{array}{l}95 \% \text { 。英国で } \\
\text { はトップレベ } \\
\text { ルの卒業率。 }\end{array}$ & 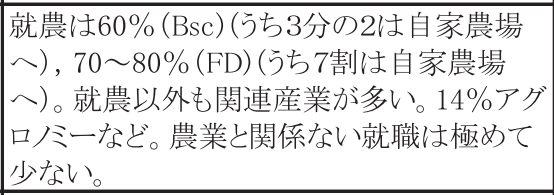 & $\begin{array}{l}\text { •国外の学生を増やす(学部レベル)。 } \\
\text { •農業のバックブランドを持たない学生を } \\
\text { 引き付ける。 } \\
\text { •生物学を勉強していない入学者が増え } \\
\text { ている。 }\end{array}$ \\
\hline RAC & ほぼ全員。 & $\begin{array}{l}\text { 求人は多い。9割以上は卒業時に職を得 } \\
\text { る。ただし経済情勢にも大きく影響をうける。 } \\
\text { OBからの引き合いも強い。 }\end{array}$ & $\begin{array}{l}\text { 学生数の増加により実習等の授業の実施 } \\
\text { が難しいことがある。 }\end{array}$ \\
\hline Bicton & - & $\begin{array}{l}\text { 自家農場に戻るケースがほとんど。もしくは } \\
\text { HEへの進学。 }\end{array}$ & $\begin{array}{l}\text { ·FD運営コスト。プラクティカルである方が } \\
\text { コストがかかる。機械・施設も整えないとい } \\
\text { けない。 }\end{array}$ \\
\hline Nottingham & $\begin{array}{l}\text { ほぼ全員。学 } \\
\text { 位は就農に } \\
\text { 有効。 }\end{array}$ & $\begin{array}{l}\text { 多様な進路がある。農場 (兼業含む), コン } \\
\text { サルタント, 農業関連産業(資材・流通)，政 } \\
\text { 府・関係団体 }(\mathrm{ADAS}), \text { その他 (銀行)。 }\end{array}$ & $\begin{array}{l}\text { •農場家族は減少。いかにその他のバック } \\
\text { グランドの学生を集めるか。 } \\
\text { •総合的な教育・研究ができるスタッフの } \\
\text { 確保 }\end{array}$ \\
\hline Duchy & ほぼ全員 & $\begin{array}{l}\text { •地域の経済情勢がよくないので, 就職先が } \\
\text { 見つけにく、傾向。自家農場へ戻るケース } \\
\text { が多い。 }\end{array}$ & $\begin{array}{l}\text { •EU等から多額の予算が投入されてい } \\
\text { る。持続的な運営には長期的に課題を残 } \\
\text { している。 }\end{array}$ \\
\hline
\end{tabular}

資料：聞き取り調査により作成 
農場の規模の小ささ（39\%）といら結果になった. これらを農場出身，非農場出身別にみると，農業の 收益性の低さはそれぞれ $65 \%$ ，48\%，資本不足は $41 \% ， 75 \%$ ，家族農場の小規模性は $51 \% ， 8 \%$ が指 摘している. 寸なわち, 非農場出身者にとっての就 農への最大の障壁は資本不足であることが明らかに されている. この状況は, 2000 年代後半の穀物価格 高騰による收益性改善により変化しているとも考光

\section{表 5. RAC における農業コースカリキュラム}

\begin{tabular}{|c|c|}
\hline \multirow{9}{*}{ FD1 年次 } & Accounts and Economics \\
\hline & Animal and Crop Sciences \\
\hline & Crop Production \\
\hline & Estate Management \\
\hline & Farm Business Management \\
\hline & General Agriculture \\
\hline & Livestock Husbandry \\
\hline & Machinery and Buildings \\
\hline & Personal Development/Employability \\
\hline \multirow{9}{*}{$\mathrm{FD} 2$ 年次 } & Work-Based Learning \\
\hline & Agricultural Policy and Legislation \\
\hline & Animal Production \\
\hline & Crop Management \\
\hline & Environmental and Woodland Management \\
\hline & Commodities Marketing \\
\hline & Machinery Management \\
\hline & Data Handling and Technical Writing \\
\hline & Farm Business Planning \\
\hline \multirow{3}{*}{$\begin{array}{l}\text { BSc(Hons) } \\
\text { 必修科目 }\end{array}$} & Integrated Farm Project \\
\hline & World Agricultural Development \\
\hline & Dissertation \\
\hline \multirow{19}{*}{$\begin{array}{c}\text { BSc(Hons) } \\
\text { 選択科目 } \\
\text { (4科目) }\end{array}$} & Advanced Animal Production \\
\hline & Advanced Crop Production \\
\hline & Climate Change and Development \\
\hline & Advanced Crop and Plant Science \\
\hline & Agricultural and Equine Journalism \\
\hline & Game and Deer Management \\
\hline & Sustainable Agricultural Strategies \\
\hline & Environmental Management \\
\hline & Farm Machinery Management \\
\hline & Rural Business Diversification \\
\hline & Soil Analysis and Interpretation \\
\hline & GIS modeling of the environment \\
\hline & Sustainable Management of Soil and Water \\
\hline & Organic Production and Marketing \\
\hline & Corporate Finance \\
\hline & Marketing Communications \\
\hline & Consumer Behaviour \\
\hline & Wine Industry \\
\hline & Farmland Ecology \\
\hline
\end{tabular}

注 : FD は Agriculture and Farm Management コース, BSc (Hons) は Agricultural Management コースを抜粋. 資料：RAC資料より整理
られるが，各担当者のコメントからは，資本不足の 問題は本質的に変化していないことが推察される.

\section{（3）農業コースにおけるカリキュラムの特徵}

農業コースに抢路カリキュラムについては，RAC を例に表 5 にまとめた。基礎学位コースでは，農業 全般（耕種，畜産，経営，機械，法律，環境など) を学ぶ体制となっている.

学士コースに進学した場合, より専門に特化した 形で選択科目を履修する形となっている.

学士コースの場合, 1 年間のワークプレースメン 卜（就業体験）を入れることができる.プレースメ ント先の選択は学生の自主性に委礼られていが, 活用実態は大学により異なる. Harper Adamsや RACでは積極的に活用され，「就職のきっかけにな るケースも多い」（RAC）が，「学生にいかに興味を 持たせるかが課題」(Nottingham),「自家農場をプ レースメント先に選択するケースが目立つ」 （Bicton）といったコメントも聞かれた.

また，既存農業者向けにはパートタイムコースや 短期集中コースなどを用意している。特に農薬散布 資格など必須のものを除くと，実績は少ないのが現 状である，パートタイムコースについては，既に農 業者として働いている者が，働きながら学位を取得 するケースは対象事例に执いては確認することがて きなかった。このような機会は流とんぞ整備されて いないのが現状だと思われる。

\section{5. 考察・まとめ}

以上の結果から，英国農業に和ける人材育成につ いて，農業教育機関の役割と問題点についてまとめ ると以下の諸点が指摘できる.

第一に，農業そのものの展望については，必ずし も悲観されているわけではない，教育機関としては， 世界的な食料需給のひっ迫や食への関心の高まりと いら状況と, 英国内に打ける農業従事者の減少とい ら両面を捉光, 従来の農家出身者に加光, 表 4 で示 したよらに非農家出身者や国外からの留学生などの 人材をいかに大学に引き付けるかを課題としている.

第二に，農業大学等で教育を受ける者の多くは農 場出身者であり，卒業後に農場に戻ることが想定さ れるが, 非農場出身者も一定の割合で存在している. これは，彼らにも一定の教育機会が確保されている ことを表す一方，参入機会は十分でないことも示し 
ている．英国には新規参入支援策「Fresh Start」プ ログラムや州政府農場なぞ，新規参入機会を創出す る制度も存在するが（内山［8]），資本不足をいか に解消するかが課題として残っている. 換言すれば, イングランドに抢任る農業教育機関は農業に括ける 教育機会を提供してきたが，農場出身者に対する教 育機会の提供のみならず，非農場出身者など多様な 人材による農業への参入機会にいかにつなげていく かを課題として突き付けているといえる.

第三に，農業教育機関卒業生は，農業そのもので なくても, 農業資材企業, 食品流通企業, 政府機関・ 関係団体，農業アドバイザー・コンサルタント業界 ${ }^{4}$ などに就職している，農業教育機関は，農業者を育 成するのみならず，農業関連産業に対して人材を供 給する役割も担っているといえる.

末筆ながら，本論では農業教育機関の“入口”と “出口”についてみたが, ぞのような教育コンテン ツが農業者育成にとって重要なのか, といった内容 にまでは踏久込むことができなかった，また，表 1 で示したよらに，減少傾向にあるとはいえ，英国に は非農場出身者でも農業キャリアを構築できる雇わ れマネジャーといら職種も存在する. これらの人た ちが従事する農業経営は大規模であることが想定さ れるが，そのよらな農業経営内で行わ玌ている人材 育成も重要な論点であり, 農業法人等への雇用型就 農が増加している日本への含意を導く意義も大き い. これらを記して今後の課題としたい.

注 1）英国の教育制度の詳細は, ECAEA [2] に学んだ.

2) Wye や Seale-Hayne などの農業系の大学・学部が 閉鎖されたのはこの時期に当たる.

3）英国の大学では授業料の值上げが続いて扣り, 2009 年以降の在籍者の急増は, ギャップイヤーを 経ずに值上げ前の授業料基準で入学する学生が増 えたことにも起因する.

4）1990年代までに普及組織が民営化した英国では, 大規模農家や農家グループが有料のアドバイザ リーサービスを利用しているケースが多い。聞き
取りによれば，アドバイザリーサービスの利用が, 銀行融資の条件となっている場合も多いという。

[付記]本論は, 科学研究費補助金（課題番号 23248038）による研究成果の一部である.

\section{参考文献}

[1] ADAS Consulting Ltd., "Entry to and Exit from Farming in the United Kingdom”, Final Report for Defra, RMP2037, 2004, p. 66

[2] Education, Audiovisual \& Culture Executive Agency (EACEA), "Organisation of the education system in the United Kingdom-England, Wales and Northern Ireland 2009/2010”, European Commission, 2012, p. 631.

[3] Gasson, R., 'Educational Qualifications of UK Farmers: A Review', Journal of Rural Studies, 14(4), 1998, pp. 487-498.

[4] Policy Commission on the Future of Farming and Food "FARMING \& FOOD, a sustainable future", 2002.

[5]内山智裕「イギリスに打ける外国人季節農業 雇用の制度変化と課題」, 『農林業問題研究』 46(1)（2010 年 6 月), pp. 104-109.

[6]内山智裕「イギリスに打ける農業経営請負会 社の現状分析一イングランド南西部 V 社の事 例一」, 『農業経済研究』2010 年度別冊（日本 農業経済学会論文集）（2010 年 12 月）, pp. 344-349.

[7]内山智裕「英国に颃ける農業キャリアパスの 存立可能性一イングランド南西部に打ける農 業への新規参入者に注目して一」, 『農業経済 研究』76(3)（2004 年 12 月）, pp. 149-159.

[8] 内山智裕「英国に打ける農業への新規参入の 制度と課題一イングランド南西部 Devon 州を 事例として一」, 『農業経営研究』42(1)（2004 年 6 月), pp. 187-190.

（受理日：2013 年 3 月 11 日） 